\title{
A descriptive study of facial lacerations presenting to pediatric emergency in Turkey
}

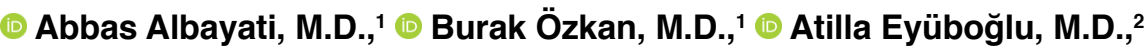 \\ 다 Çağrı A Uysal, M.D., ${ }^{1}$ ㅇ Nilgün M Ertaş, M.D. ${ }^{1}$
}

${ }^{1}$ Department of Plastic, Reconstructive and Aesthetic Surgery, Başkent University Faculty of Medicine, Ankara-Turkey
${ }^{2}$ Department of Plastic, Reconstructive and Aesthetic Surgery, Memorial Bahçelievler Hospital, İstanbul-Turkey

ABSTRACT

BACKGROUND: Soft tissue trauma of the face is considered a leading cause of presentation and referral to the pediatric emergency department. The present study aims to evaluate the demographics properties of facial injuries presenting to the pediatric emergency.

METHODS: In this study, II60 patients presented with a simple facial laceration to the pediatric emergency department of Başkent University were reviewed from 20II to 2017. Patients up to 18 years of age were included. We evaluated demographics about patients' age, sex, the cause of injury, the location of laceration and timing of the injury. Age was categorized according to the National Institute of Child Health and Human Development (NICHD) pediatric terminology into five groups as follows: 0-12 months, 12 months-2 years, 2-5 year, 6-1I year, and I2-18 years. The following analyses were performed to each age group: a number of cases, male to female predominance, timing of injury (e.g., early morning, afternoon, evening, late evening and at night), the place that the injury has occurred (e.g., at home, at school, in sport hall), the cause of injury (fall, hitting a hard subject, sports-related), the location of laceration (forehead, periorbital area, cheek, perioral area, nose, submental area) and the incidence according to the season.

RESULTS: Number and relative percentages of cases were as follows: $0-12$ months ( $n=127,10.9 \%), 12-24$ months ( $n=113,9.7 \%$ ), $3-5$ years $(n=385,33.1 \%), 6-11$ years $(n=403,34.7 \%)$ and $12-17$ years $(n=132,11.3 \%)$. The average age of children was 6.5 year $($ range, 5 month - 17.9 year). The age group 6-II showed a higher incidence compared to other age groups $(n=403,34.7 \%)$. Fifty-three percent of the population was younger than six years and there was a male predominance in all age groups.

CONCLUSION: The demographic data provided in this study can be useful in trauma prevention programs which are effective in reducing the incidence, nature and severity of facial lacerations. Parents should be reminded of age-specific preventive measures in injury avoidance.

Keywords: Demography; fall; facial wounds.

\section{INTRODUCTION}

The face is important to human appearance and function. Facial injuries have psychological and social outcomes. Facial lacerations have always been a source of concern for parents. The fear of lifelong lasting marks on the face of their children makes the parents worry about the possible scar. The management of these cases necessitates a good functional and cosmetic result.
Facial trauma is extremely common in the pediatric population. In 2007, the number of emergency room (ER) visits in the United States for open wounds of the head in patients younger than 15 years was 370,000 and 434,000 for girls and boys, respectively. ${ }^{[1]}$

Worldwide, the etiology of facial trauma is fall, hitting the wall, furniture related, sports injuries, traffic accidents, and assaults. The spectrum of trauma ranges from a simple lacer-

Cite this article as: Albayatı A, Özkan B, Eyüboğlu A, Uysal ÇA, Ertaş NM. A Descriptive study of facial lacerations presenting to pediatric emergency in Turkey. Ulus Travma Acil Cerrahi Derg 2021;27:61-66.

Address for correspondence: Abbas Albayati, M.D.

Başkent Üniversitesi Tıp Fakültesi, Plastik, Rekonstrüktif ve Estetik Cerrahi Anabilim Dalı, Ankara, Turkey

Tel: +90 312 - 2036868 E-mail: albyatil7@gmail.com

Ulus Travma Acil Cerrahi Derg 202I;27(I):6I-66 DOI: 10.14744/tjtes.2020.57879 Submitted: 27.09.20I9 Accepted: 30.03.2020 Online: 09.12.2020

Copyright 2021 Turkish Association of Trauma and Emergency Surgery 
ation to life-threatening trauma. The change in the behavioral model of children, distinct anatomical features of each age group and certain cultural and socioeconomic variables affect the etiologic factors, the pattern and the extent of the injury, the sex incidence and the management of these injuries.

Several studies from different countries have discussed the epidemiology of facial soft tissue injuries in the pediatric population. ${ }^{[2,3]}$ However, in Turkey, most published data focused on facial trauma in adult patients. There is an inadequacy in the published studies on the demography of facial injuries in children. Therefore, we aimed to evaluate the demography of facial lacerations in pediatric patients of less than 18 years old treated using the Plastic, Reconstructive and Esthetic department at Başkent University in Ankara, Turkey.

\section{MATERIALS AND METHODS}

In this study, I 160 patients presented with a simple facial laceration to the pediatric emergency department of Başkent University were reviewed retrospectively from 20II to 2017. Patients up to 18 years of age were included. All patients were managed by our Plastic and Reconstructive department. We excluded simple lacerations that do not necessitate suturing, intraoral lacerations and cases of facial wounds associated with maxillofacial fractures. We gathered information about patients' age, sex, the cause of injury, the location of laceration and the timing of the injury. Age was categorized according to the National Institute of Child Health and Human Development (NICHD) pediatric terminology into five groups as follows: 0-12 months (infancy), 12 months-2 years (toddler), 2-5 year (early childhood), 6-II year (middle childhood) and 12-18 years (early adolescence). The following analyses were performed to each age group: the number of cases, male to female predominance, the timing of injury (e.g., early morning, afternoon, evening, late evening and at night), the place the injury occurred (e.g., at home, at school, in sports hall), the cause of injury (fall, hitting a hard subject, sports-related), the location of laceration (forehead, periorbital area, cheek, perioral area, nose, submental area), and the incidence according to the season. This study was approved by Baskent University Institutional Review Board (Project no: KAI9/239) and supported by Baskent University Research Fund.

\section{RESULTS}

\section{Age and Sex Distribution}

One thousand one hundred sixty patients were evaluated for this study. The total numbers and relative percentages of cases were as follows: $0-12$ months $(n=127,10.9 \%), 12-24$ months $(n=1 \mid 3,9.7 \%), 3-5$ years $(n=385,33.1 \%), 6-1 \mid$ years $(n=403,34.7 \%)$ and $12-17$ years $(n=132,11.3 \%)$. The age group, 6-II, showed a higher incidence compared to other age groups $(n=403,34.7 \%)$. The average age of children was 6.5 year (range, 5 months-17.9 years). Fifty-three percent of the sample was younger than six years and there was a male predominance in all age groups and male to the female ratio varied according to age (Fig. I).

\section{Place of Injury}

Most of the injuries occurred indoor $(n=700,60.3 \%)$ with the incidence being highest in the age group 0-12 months $(n=112,88.1 \%)$ and lowest in the age group $12-17$ years $(n=50,37.8 \%)$. Outdoor injuries increased with age (from $7.8 \%$ in the age group $0-12$ months to $20.4 \%$ in the age group $1 \mathrm{I}-17$ years). Injuries that took place at school and in playgrounds were highest in the age group $6-11$ years $(n=73$, $18.1 \%$ and $n=70,17.3 \%$ ), respectively (Fig. 2).

\section{Site of Laceration}

Frontal area was the most common site of injury $(n=385$, $33.1 \%)$ followed by periorbital $(n=280,24.1 \%)$ and submental lacerations $(n=234,20.1 \%)$. Forehead lacerations were the most common in all age groups except for the age group 1217 years, where periorbital area injuries and submental lacerations were slightly higher $(n=39,29.5 \%$ and $n=28,21.2 \%$, respectively). Forehead lacerations decreased with age (from $45.6 \%$ in the age group $0-12$ months to $16.6 \%$ in the age group II-I7 years). Injuries over the dorsum of the nose were the lowest area involved $(n=37,3.1 \%)$. Laceration in the mental and submental area raised noticeably in the age group 3-5 ( $n=94,24.4 \%)$ (Fig. 3).

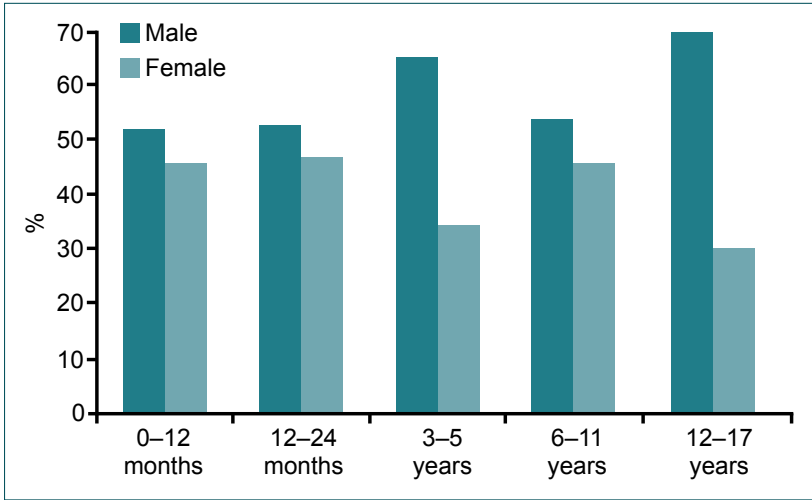

Figure 1. Age-related sex incidence.

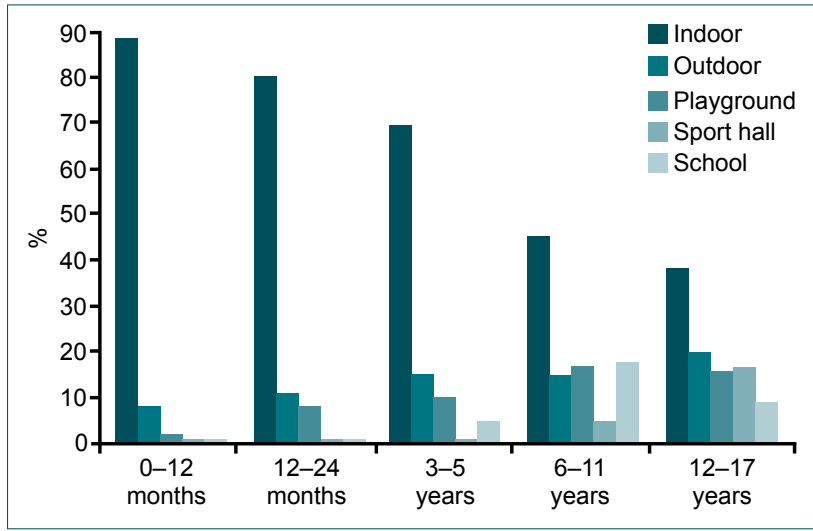

Figure 2. Age-place related incidence. 


\section{Cause of Injury}

The most frequent etiology of injury in all age groups was falls $(n=532,45.8 \%)$ followed by hitting the wall or solid objects ( $n=445,38.3 \%$ ) (Fig. 4). Sports-related injuries were observed in the age group $6-11$ years $(n=20,4.9 \%)$ and the incidence was higher in the age group $12-17$ years $(n=22,16.6 \%)$. Physical conflicts were noticed in the age group 6-II years and $12-17$ years $(n=12,2.9 \%)$ and $(n=I \mid, 8.3 \%)$, respectively. Injuries from road traffic accidents were the least frequent cause of injury $(n=22,1.8 \%)$.

\section{Time of Injury}

Most injuries occurred between 16.00 and 20.00, and least frequently between 04.00 and 08.00 . In infants less than two years of age, injuries most frequently occurred from 20.00 to 24.00 (Fig. 5).

\section{Season of Injury}

There was a slight increase in cases presented during summer $(n=340,29.3 \%)$, while cases presented in winter showed a slight increase in older age groups. The distribution of cases according to the season is illustrated in Fig. 6 .

\section{Mode of Treatment}

Uncooperative children younger than six years were sutured under sedation or general anesthesia $(n=450,72 \%)$. Most of

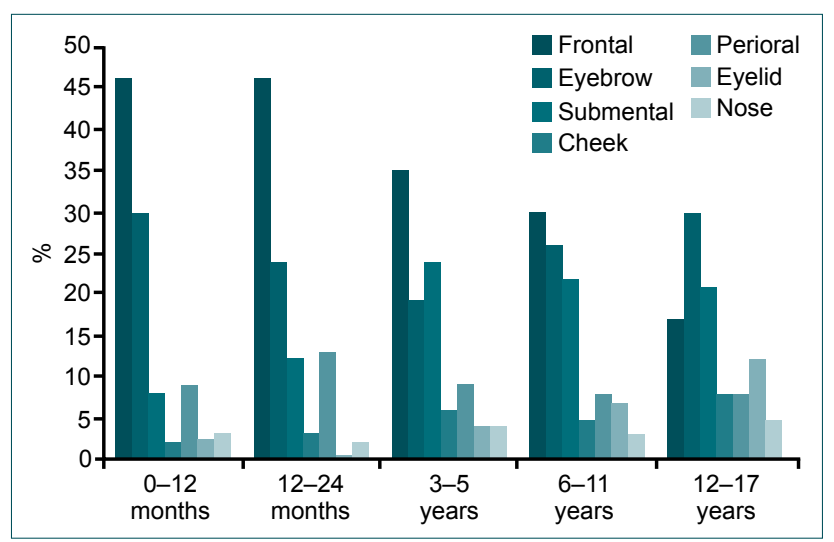

Figure 3. Age-site related incidence.

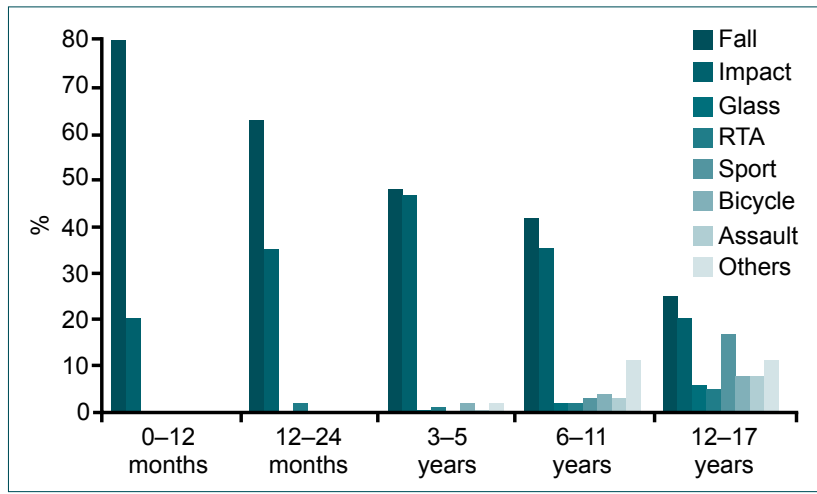

Figure 4. Cause of the injury. the patients older than six years were treated under local anesthesia ( $n=481,89.9 \%$ ) (Fig. 7).

\section{DISCUSSION}

Facial soft tissue trauma is of uttermost importance in the pediatric population as even mild injuries may cause functional and esthetic deformities. The incidence is determined by environmental and socioeconomic variables. The incidence of facial trauma is increasing gradually, probably because of a high level of physical activities, decreased supervision, and a tendency toward children's aggressive behaviors. ${ }^{[4]}$ British

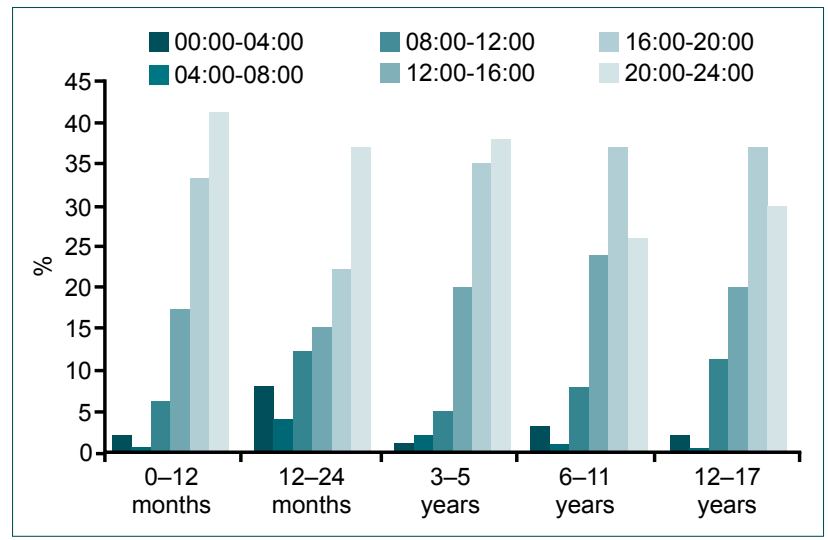

Figure 5. Time of injury.

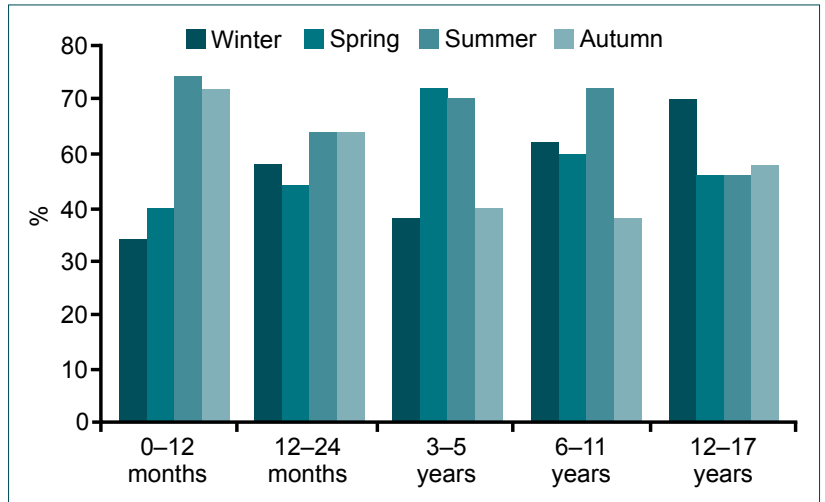

Figure 6. Incidence according to the season.

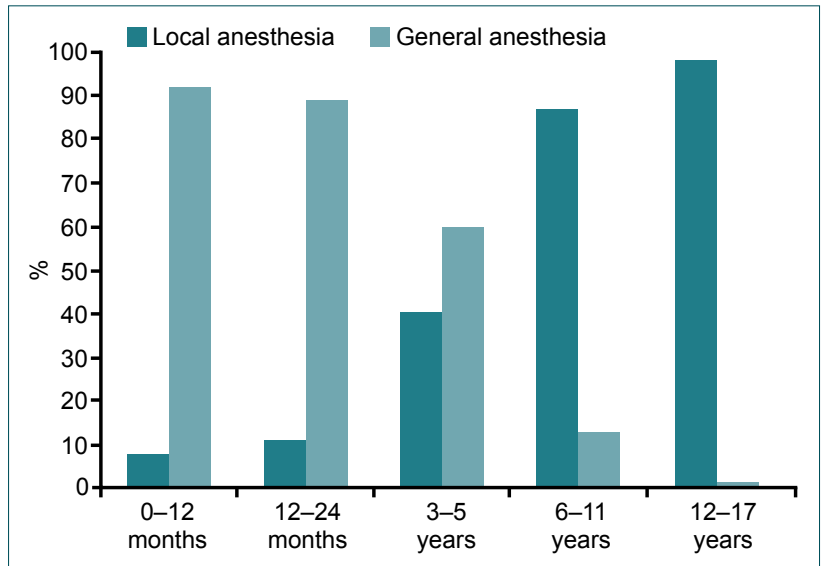

Figure 7. Mode of the treatment. 
Association of Oral and Maxillofacial Surgery reported that children below the age of 15 account for $39 \%$ of all facial trauma cases presenting to ER departments in the UK. ${ }^{[5]}$

Most epidemiological studies on maxillofacial trauma focus on facial fractures ignoring soft tissue injuries despite being more common than facial fractures. Other studies discuss the cosmetic outcomes comparing different treatment methods with no emphasis on epidemiological analyses. ${ }^{[6]}$ In the present study, we illustrate demographic analyses of patients presenting to the emergency department according to age groups, to our knowledge, being the first epidemiological study on facial lacerations in Turkish children to date.

The pattern of injury, etiology and the treatment of facial lacerations vary within different age groups. The most affected age group was 6-II years. McGraw and Cole reported that facial trauma was infrequent between ages $0-5$ years. ${ }^{[7]}$ In our sample, $53 \%$ of the cases were less than six years of age. This observation is like that of recent studies, showing that facial soft tissue injuries are common in young age groups. ${ }^{[3,6]}$

The male population was injured more commonly in the present study (overall male to female ratio: I.4:I), consistent with the literature, as boys are more prone to risk-taking behaviors. ${ }^{[3,6,8,9]}$

Most cases in children less than six years of age are because of falls. The prevalence of falls as a leading cause of facial trauma in young children has been reported in different studies, explained by motor development and child behavior. ${ }^{[2,6,8,10]}$ Although continued to be the most common cause of injury in older age groups, the incidence of fall decreased in these age groups, followed by hitting the head on a solid subject, bicycle accidents, assaults, sports -related trauma, and motor vehicle crashes.

Sports like football, basketball, and skiing account for an occasional incidence of facial injuries in adolescents. Sports-related wounds mainly occurred while playing basketball. These wounds are mostly caused by collisions from other players. Most of the cases presenting due to sports injuries or assault were male.

In the older age group, falls from bikes and playground injuries (e.g., swing, slides and overhead ladder) were among the leading causes of injury following mechanical falls.

Playgrounds made of concrete and asphalt is not suitable as playgrounds for kids, in contrast to that made of rubber that renders these injuries less dangerous. Thus, using soft and elastic materials to cover indoor playgrounds is advised because $80 \%$ of indoor head trauma is because of solid surfaces.

Parents are likely to bring their children to parks that contain equipment designed especially for excitement and challenge.
These games are not safe for all ages. Child health organization recommends attending playgrounds that are subjected to regular control, and those split for children and adults with relevant equipment and instructions for all ages.

The incidence of bicycle accidents was the highest in the age group $12-17$ years (8.3\%). These injuries are usually associated with multiple injuries affecting more than one site.

Animal bites are among the reported causes of facial injury, especially in children under five years of age..$^{[1]}$ In our study, we did not observe an injury from an animal bite. Possible reasons for this are as follows: the injury could be a simple scratch that was managed primarily by the ER and was not referred to our clinic. Another likely reason is the area injured could be the ear, in which case patients are referred to Otolaryngologist.

Facial soft tissue injuries from RTA were the least frequent cause of injury. These injuries are mostly accompanied by facial fractures due to high collision force and thereby been excluded from our study. Another reason for this low incidence could be following safety measures, including seat belts or childhood restraints. There was no reported laceration because of child abuse in our sample. This may be due to a failure to recognize this pattern by hospital staff.

As expected, school injuries increase with age. Therefore, safety management in school is important.

Forehead lacerations were much more common in younger age groups. Some authors have attempted to explain this increased incidence in this type of injuries; the underdevelopment of neck muscles and the bigger size of the head in relation to the body in children less than two years are the reasons most of the lacerations are in the forehead in this age group making this region precisely subjected to trauma. [7,10] In addition, as the child grows, with the development of paranasal sinuses, the ratio of cranium-face becomes $2: I$, whereas for an adult individual, it is estimated to be $8: 1^{[6]}$ Thereby, forehead lacerations decrease in incidence in an inverse proportion to the age. As the child grows older, they tend to protect their face while falling down. Thus, submental lacerations showed a steady increase in incidence as the age progresses. Most of the forehead lacerations seen indoor are sustained due to slip/trip against the wall, table or sofa, making the padding of furniture an effective preventive measure. ${ }^{[8]}$

Lacerations in mental and submental regions should be evaluated carefully as they are occasionally associated with mandibular fractures.

In our study, we also showed an increasing prevalence of periorbital lacerations with increasing age. Eyelid injuries are witnessed more frequently in children sustaining ocular trauma while wearing eyeglasses. Assessment of ocular trauma may require further ophthalmologic consultation. 
Cheek was one of the least involved areas. The function of the facial nerve and its branches should be assessed in case of deep lacerations to the cheek. The possibility of parotid duct injury should always be kept in mind in such injuries.

Although the nasal bone is the most commonly damaged bone in maxillofacial fractures, soft tissue injuries of the nose are the least encountered in cases of facial trauma in the pediatric population. ${ }^{[12]}$ Only $3 \%$ of cases were presented with lacerations over the nose. In cases of nasal trauma, nasal $X$-ray is indicated.

Most of the cases witnessed between 16.00 and 20.00 o'clock. This timely increase may be explained by the lack of parents' attention at the end of a working day.

There was a mild seasonal variation in the incidence of facial lacerations as the physical activities of children may vary depending on seasonal changes. There was a minimal increase in the number of cases in the summer season, but statistically, it was not relevant. The increase in cases presented during the winter months is witnessed in the older age group. This may be explained by cases that occurred in school. On the other hand, some authors reported a reduced incidence in summer as it is coincident with school holidays where most families travel on vacations. ${ }^{[9,13]}$

The main goals of the management of facial lacerations are obtaining an optimal functional and cosmetic result. Treatment of facial lacerations presents a more challenging procedure in the pediatric population compared with adults. Performing a satisfactory treatment is not an easy duty. The successful treatment combines the skill of careful anesthesia application, avoidance of distress and distracting the child while suturing.

A detailed history regarding the environment, the timing and the impact of forces involved in the trauma. Physical examination should be performed carefully to avoid misdiagnosing facial fractures. Knowing the mechanism of injury and the pattern of trauma is a clue to estimate the extent of injury and diagnosis of an underlying skeletal injury. Examination under local anesthesia may facilitate the proper assessment of facial wounds. However, local anesthesia infiltration should only be administered after proper sensory examination of the face to avoid skipping a nerve injury. Special consideration is paid to the location, length and edges of the wound. Presence of a foreign body and if any underlying structure has been exposed is noted. Further evaluation is guided by the nature of the wound.

The initial assessment of facial trauma is with plain films. Although a CT scan is the preferred method, it is rarely indicated in simple facial lacerations. CT scan is indicated if there is an extensive trauma with generalized tenderness, or a fracture line is seen in a radiograph.

Although basic principles of wound care and repair are the same, certain considerations are taken into account accord- ing to the developmental age of the child. Explaining the procedure to a cooperative child in a calm and understandable language can help reassure the patient and establish communication with the child. Distraction methods, such as phones, bubbles, and imagery, are useful to drive the attention of the child. Parents are informed briefly about the possible treatment modalities and the expected cosmetic outcomes.

All essential and necessary equipment is prepared before embarking on treatment. Needles and sutures are kept out of the child's visual axis to avoid provoking an already irritated child. Parents or caregivers are allowed to stay beside the child during the procedure. This may help ease the child's stress, especially when the area to be sutured is covered with a sterile drape, which increases the stress.

Sedation is becoming much more common outside the operating room, mainly because of health care trends of more cost-effective measures. ${ }^{[14]}$ Sedation and general analgesia is used for uncooperative children less than six years of age, patients with behavioral problems, for those with lacerations in an aesthetically demanding area, for example, lip or alar area, for multiple lacerations and in case of eyelid lacerations. A fasting period of at least hour hours for liquid and six hours for food is ensured before sedation. Patients receiving sedative drugs were followed for at least two hours in the ER and discharged with instructions. Almost $90 \%$ of our patients older than six years of age were treated in the ER under local anesthesia, while $72 \%$ of patients younger than six years were sutured under sedoanalgesia.

Prophylactic antibiotics are usually not required for simple facial wounds. Indications for prophylaxis against infection are bite wounds, excessive wound contamination that is closed primarily, wounds with exposed cartilage and penetrating wounds to the buccal mucosa. Tetanus prophylaxis is provided according to the vaccination status of the patient.

The threshold for plastic surgery consultation in facial lacerations by ER is very high since the pediatric emergency department in our hospital is operated by pediatricians only with no qualified trauma staff. Thus, we believe that the scope of our study is satisfactory in providing accurate epidemiology since all patients presented with facial lacerations were referred to the plastic and reconstructive surgery unit. This work may be considered as the first study to provide a descriptive analysis of facial lacerations presenting to the pediatric emergency in Turkey. Regarding the limitations of this study, this study is based on patients presenting to our institute in Ankara only, which lies in the central region of Turkey. The findings obtained in this study may be representative of people living in this part of Turkey. Thus, further studies should include multicenter institutions throughout the country.

\section{Conclusion}

Facial soft tissue trauma is common in pediatric age groups 
and presents a source of anxiety for the parents. The findings of our study regarding soft tissue lacerations of the face are consistent with previous similar studies in the literature. The best method to decrease the incidence of pediatric injuries is to take preventive measures. Parents are advised to take preventive measures according to the age of the child and the environment the child is in. Safety precautions should be taken for indoor injuries, such as shielding the edges of furniture and the corners of the wall. We emphasize the rule of public preventive measures in reducing the incidence of facial trauma. The demographic data provided in this study can be useful in trauma prevention programs that are effective in reducing the incidence, nature and severity of facial lacerations.

Ethics Committee Approval: Approved by the local ethics committee (date: 17/07/2019, no: 94603339604.01.02/25586).

Peer-review: Internally peer-reviewed.

Authorship Contributions: Concept: B.Ö.; Design: B.Ö.; Supervision: N.M.E.; Resource: A.A.; Materials: A.E.; Data: A.A., A.E.; Analysis: N.M.E.; Literature search: A.A.; Writing: A.A.; Critical revision: Ç.A.U.

Conflict of Interest: None declared.

Financial Disclosure: The authors declared that this study has received no financial support.

\section{REFERENCES}

1. Niska R, Bhuiya F, Xu J. National Hospital Ambulatory Medical Care Survey: 2007 emergency department summary. Natl Health Stat Report
2010;(26):1-31.[CrossRef]

2. Rocchi G, Fadda MT, Marianetti TM, Reale G, Iannetti G. Craniofacial trauma in adolescents: incidence, etiology, and prevention. J Trauma 2007;62:404-9. [CrossRef]

3. Islam S, Ansell M, Mellor TK, Hoffman GR. A prospective study into the demographics and treatment of paediatric facial lacerations. Pediatr Surg Int 2006;22:797-802. [CrossRef]

4. Hogg NJ, Horswell BB. Soft tissue pediatric facial trauma: a review. J Can Dent Assoc 2006;72:549-52.

5. Hutchison IL, Magennis P, Shepherd JP, Brown AE. The BAOMS United Kingdom survey of facial injuries part 1: aetiology and the association with alcohol consumption. British Association of Oral and Maxillofacial Surgeons. Br J Oral Maxillofac Surg 1998;36:3-13. [CrossRef]

6. Shaikh ZS, Worrall SF. Epidemiology of facial trauma in a sample of patients aged 1-18 years. Injury 2002;33:669-71. [CrossRef]

7. McGraw BL, Cole RR. Pediatric maxillofacial trauma. Age-related variations in injury. Arch Otolaryngol Head Neck Surg 1990;116:41-5.

8. Chang LT, Tsai MC. Craniofacial injuries from slip, trip, and fall accidents of children. J Trauma 2007;63:70-4. [CrossRef]

9. Collao-González C, Carrasco-Labra A, Sung-Hsieh HH, Cortés-Araya J. Epidemiology of pediatric facial trauma in Chile: a retrospective study of 7,617 cases in 3 years. Med Oral Patol Oral Cir Bucal 2014;19:e99-105.

10. Gassner R, Tuli T, Hächl O, Moreira R, Ulmer H. Craniomaxillofacial trauma in children: a review of 3,385 cases with 6,060 injuries in 10 years. J Oral Maxillofac Surg 2004;62:399-407. [CrossRef]

11. Abuabara A. A review of facial injuries due to dog bites. Med Oral Patol Oral Cir Bucal 2006;11:E348-50.

12. Cakabay T, Ustun Bezgin S. Pediatric Nasal Traumas: Contribution of Epidemiological Features to Detect the Distinction Between Nasal Fractures and Nasal Soft Tissue Injuries. J Craniofac Surg 2018;29:1334-7.

13. Posnick JC, Wells M, Pron GE. Pediatric facial fractures: evolving patterns of treatment. J Oral Maxillofac Surg 1993;51:836-45. [CrossRef]

14. Kaplan RF, Yang CI. Sedation and analgesia in pediatric patients for procedures outside the operating room. Anesthesiol Clin North Am 2002;20:181-vii. [CrossRef]

\section{ORIJIINAL ÇALIŞMA - ÖZET}

\section{Pediatrik acile başvuran yüz bölgesindeki laserasyonların tanımlayıcı incelenmesi}

\section{Dr. Abbas Albayati, ${ }^{1}$ Dr. Burak Özkan, ${ }^{1}$ Dr. Atilla Eyüboğlu, ${ }^{2}$ Dr. Çağrı A Uysal, ${ }^{1}$ Dr. Nilgün M Ertaş ${ }^{1}$}

${ }^{1}$ Başkent Üniversitesi Tıp Fakültesi, Plastik, Rekonstrüktif ve Estetik Cerrahi Anabilim Dalı, Ankara
${ }^{2}$ Memorial Bahçelievler Hastanesi, Plastik, Rekonstrüktif ve Estetik Cerrahi Anabilim Dalı, İstanbul

AMAÇ: Yüz travması pediatrik çağında son derece yaygındır. Pediatrik acile sevk ve başvuruların önde gelen sebeplerin arasında düşünülmektedir. Bu çalışmanın amacı yüz kesileri ile pediatrik acile başvuran hastaların demografik özelliklerinin incelenmesidir.

GEREÇ VE YÖNTEM: 2012 ile 2017 yılları arasında basit yüz laserasyonu ile Başkent Üniversitesi Hastanesi pediatrik acil servisine başvuran toplam I 60 hasta geriye dönük olarak incelendi. On sekiz yaşına kadar olan hastalar çalışmaya dahil edildi. Tüm hastalara plastik ve rekonstrüktif cerrahi doktorları tarafından müdahele edildi. Ağız içi ve maksillofasiyal kırıkla ilişkili yüz kesileri olan hastalar çalışmaya alınmadı. Hastaların yaşı, cinsi, travmanın sebebi, laserasyonun konumu, travmanın zamanlaması ile ilgili bilgiler toplandı. Yaş Ulusal Çocuk Sağlığı ve İnsan Gelişimi Enistitüsü (NICHD) pediatrik terminolojisine göre beş gruba sınıflandırıldı: 0-12 ay (süt çocukluğu dönemi), 12 ay-2 yıl (oyun çocukluğu dönemi veya Toddler yaş grubu), 2-5 yıl (erken çocukluk), 6-II yıl (orta çocukluk) ve I2-I7 yıl (püberte). Her yaş grubuna şu analizler yapıldı: Olgu sayısı, erkek-kadın oranı, travmanın ve hastaneye başvurunun zamanlaması (örn. sabah, öğleden sonra, akşam, geç akşam ve gece), travmanın gerçekleştiği alan (örn. evde, okulda, spora salonunda... vs), mevsime göre insidans, travmanın türü (örn. düşme, kafayı sert bir objeye vurmak... vs) ve laserasyonun lokalizasyonu (alın, periorbital, yanak... vs).

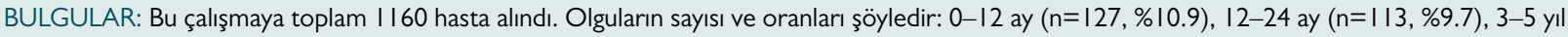

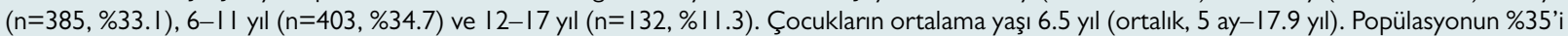
altı yaşından küçüktü. En yüksek insidans 6-II yaş grubunda görüldü. Genel olarak erkek hastalar olguların çoğunluğunu oluşturmaktaydı (\%59.3I). TARTIŞMA: Bu veriler yüz kesisi ile acil servisine başvuran hastalarla ilgili detaylı bir yorum ve gözlem sunmuştur. Bu çalışmalar Türkiye'deki yüz travması geçiren çocukların yüz kesilerinin tabiatı, oranı ve şiddetini azaltacak yaralanma önleme programlarında faydalıdır. Bu tür yaralanmalar ile ilgilenen plastik cerrah ve diğer sağıık personellerinin yaralanma önleme tavsiyelerinde bulunmaları çocukluk çağı yaralanma oranlarının azaltmasında yararlıdır. Anahtar sözcükler: Demografi; düşme; yüz kesileri. 